\title{
Arkansas StreamStats-A U.S. Geological Survey Web Map Application for Basin Characteristics and Streamflow Statistics
}

\section{Introduction}

The U.S. Geological Survey (USGS) provides streamflow and other related information needed by water-resource managers responsible for protecting people and property from floods, planning and managing water-resource activities, and protecting water quality. Streamflow statistics provided by the USGS, such as the 1-percent annual exceedance probability (100-year flood) and the 7-day 10-year low flow, are frequently used by engineers, flood forecasters, land managers, biologists, and others to guide their everyday decisions. Additionally, resource managers often need to know basin characteristics, the physical and climatic characteristics of a drainage basin, to help understand the mechanisms that control water availability, water quality, and aquatic habitats at various locations.

Users of streamflow information often require streamflow statistics and basin characteristics at various locations along a stream. The USGS periodically calculates and publishes streamflow statistics and basin characteristics for streamflowgaging stations and partial-record stations, but these data commonly are scattered among many reports that may or may not be readily available to the public. The USGS also provides and periodically updates regional analyses of streamflow statistics that include regression equations and other prediction methods for estimating statistics for ungaged and unregulated streams across the State. Use of these regional predictions for a stream can be complex and often requires the user to determine a number of basin characteristics that may require interpretation. Basin characteristics may include drainage area, classifiers for physical properties, climatic characteristics, and other inputs. Obtaining these input values for gaged and ungaged locations traditionally has been time consuming, subjective, and can lead to inconsistent results.

\section{Description of StreamStats}

StreamStats is a Web-enabled geographic information system (GIS) application that makes it easy for users to obtain streamflow statistics, basin characteristics, and other information for USGS streamflow-gaging stations and for ungaged locations of interest (Ries and others, 2008). If a user selects the location of a streamflow-gaging station, StreamStats will provide previously published information for the station from a database. If a user selects a location where no data are available (an ungaged location), StreamStats will run a GIS program to delineate the drainage basin boundary, measure basin characteristics, and estimate streamflow statistics based on USGS streamflowprediction methods. Users can download the GIS feature class of the drainage basin boundary with attributes including the measured basin characteristics and streamflow estimates.

StreamStats consists of five major components: (1) a user interface (fig. 1) that displays maps and streamflow statistics based on user-selected stream locations, (2) a database containing available streamflow statistics and descriptive information for USGS streamflow-gaging stations, (3) a GIS database that stores

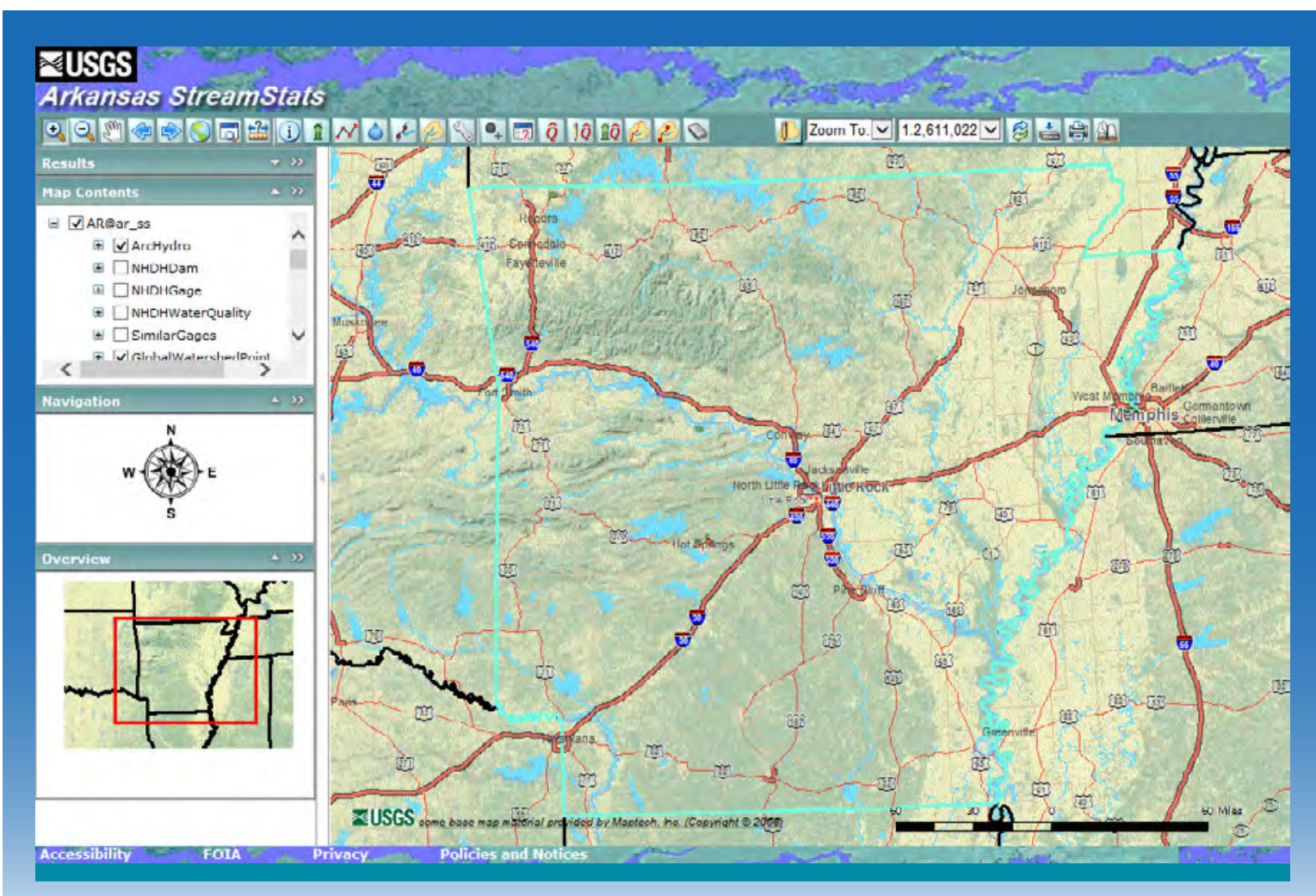

Figure 1. View of the Arkansas StreamStats user interface. 
base-map data needed by users for assigning locations and other map data needed for determining basin characteristics, (4) an automated GIS process that determines drainage-basin boundaries for userselected ungaged locations and determines basin characteristics for those locations (fig. 2), and (5) an automated process that uses USGS streamflow-prediction methods to estimate various streamflow statistics for gaged and ungaged locations based on basin characteristics (fig. 2).

StreamStats is designed for national implementation. However, because each State has its own unique streamflow prediction methods, separate applications are established for each State. Arkansas StreamStats provides stream-related information quickly and reliably without requiring users to have large investments in computer hardware and software and without requiring advanced knowledge of computer science, geographic analysis, or hydrology. The application is intended to substantially reduce the effort and subjectivity involved in the calculation of streamflow statistics by the many different users across the State. The StreamStats application was developed cooperatively by the USGS and the Environmental Systems Research Institute, Inc. The development of StreamStats for Arkansas has been a cooperative effort involving the USGS, the U.S. Forest Service, the Natural Resources Conservation Service, the Arkansas Natural Resources Commission, the Arkansas State Highway and Transportation Department, and the U.S. Army Corps of Engineers - Little Rock District.

\section{Regional Regression Equations}

Streamflow statistics for an ungaged location are determined through the use of regional regression equations. Arkansas StreamStats uses current regional regression equations developed by the USGS to determine the streamflow statistics for a user-selected point (Hodge and Tasker, 1995; Funkhouser and others, 2008). The user should be familiar with the limitations and accuracy of the regression equations before applying the resulting statistics. The following statistics can be determined from the regression equations for Arkansas:

- Low flows (annual 7-day, 2-year, 10-year; seasonal, bimonthly, and monthly 7-day, 10-year)

- Flood flows (50, 20, 10, 4, 2, 1, and 0.2 percent annual exceedance probability, which may also be defined as the maximum instantaneous flows that occur on average every 2, 5, 10, 25, 50, 100 , and 500 years)

\section{References}

Funkhouser, J.E., Eng, Ken, and Moix, M.W., 2008, Low-flow characteristics and regionalization of low-flow characteristics for selected streams in Arkansas: U.S Geological Survey Scientific Investigations Report 2008-5065, 161 p. (Also available at http://pubs.usgs.gov/sir/2008/5065/.)

Hodge, S.A., and Tasker, G.D., 1995, Magnitude and frequency of floods in Arkansas: U.S. Geological Survey Water-Resources Investigations Report 95-4224, 434 p. (Also available at http://pubs.er.usgs.gov/publication/wri95422.)

Ries, K.G., III, Guthrie, J.G., Rea, A.H., Steeves, P.A., and Stewart, D.W., 2008, StreamStats-A water resources web application: U.S. Geological Survey Fact Sheet 2008-3067, 6 p. (Also available at http://pubs.er.usgs.gov/usgspubs/fs/ fs20083067/.)

\section{By Aaron L. Pugh}
For more information, contact:
Director, Arkansas Water Science Center
U.S. Geological Survey
401 Hardin Road
Little Rock, Arkansas 72211
501-228-3600
http://ar.water.usgs.gov/

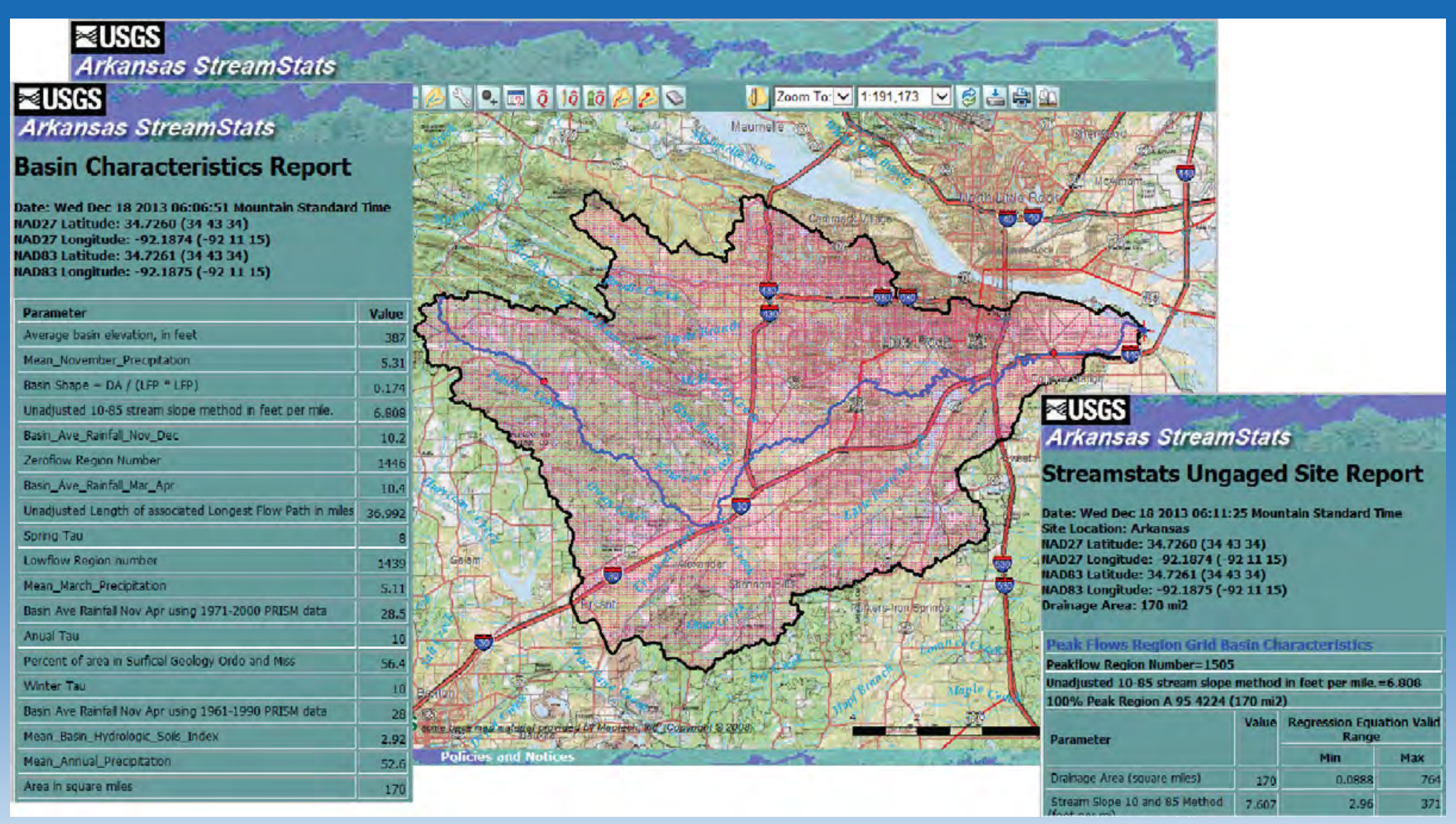

Figure 2. Basin delineation, basin characteristics report, and ungaged site report for an ungaged site on Fourche Creek using Arkansas StreamStats. 